\title{
Articles
}

\section{Human Rights, Symbolic Form, and the Idea of the Global Constitution}

\author{
By Nathan Gibbs*
}

\begin{abstract}
This Article develops a methodological basis for elaborating an idea of global constitutionalism. It applies this broader understanding of the idea of global constitutionalism to an examination of the specific role played by human rights within the evolving framework of global legal governance. The methodological basis from which the idea of global constitutionalism is developed derives from work in historical sociology that emphasizes the role played by underlying symbolic forms in the structure of social reality. The approach adopted here lays particular emphasis, following Claude Lefort and Marcel Gauchet, on the role of political theology as the principal mode in which symbolic form is constituted. From this perspective, the notion of the global human rights model is scrutinized as central to the symbolic form of global constitutionalism. Developed in critical engagement with the work of Samuel Moyn, human rights can be seen as central to global constitutionalism viewed as the latest political constellation of a distinctively secular understanding of the symbolic form and limits of political authority.
\end{abstract}

*Lecturer in Law, University of Aberystwyth. The author would like to thank Jean Christy, Charu Kulkarni and Erica Sieg for their invaluable editorial advice and comments. 


\section{A. Introduction}

In this Article, we will examine one of the central elements of an evolving global constitution: The concept or notion of the field of global human rights, a field both paradigmatic of what might be termed the global register of the meaning of law as a symbolic form and, as such, essentially contested in its key features. The central purpose of the Article is not so much to add to the empirical and doctrinal literature clarifying distinctive and important developments in this field, nor is the purpose of the Article to elaborate a conceptual basis for unifying, in a strong normative sense, a global doctrinal model for the development of human rights. Instead, the Article will seek to investigate an underlying problem for this entire field of study: Namely, the distinctive historical and ideological context in which the so-called global model of human rights protection has evolved, with a view to explaining the sense in which the idea of human rights fits within the constitutional framework of globalization. In brief, the principal purpose of the Article is to delineate the formative existential and historical basis, centered on human rights, for the globalization of constitutionalism in such a way as to set out the distinctive and fundamental set of problems encountered by human rights law on the level of a global constitution.

Accordingly, and to put the point in a more technical way, the central focus of the Article is to situate the normative and doctrinal problem - the question of the normative basis for the development of the concept of rights-understood-as-universal, a global regime of human rights - within the context of an interconnected set of historical or cultural presuppositions that form the basis for the quotidian operation of rights within its various adjudicative and jurisdictional fora. So far, the term "global" and the notion of "global constitutionalism" have been left undefined: To what extent is it useful to speak about a global constitutional model in general and a global human rights model in particular? These are evidently not new questions, and the principal lines of the debate surrounding the utility of these terms will be familiar to many readers. ${ }^{1}$ In the context of the following discussion, however, the theoretical, normative, and empirical cautions about the utility of the use of the terms global, globalization, and so on, for the purposes of legal-doctrinal or socio-legal analysis, will not be directly engaged with as such. As this Article will show, part of the reason for this is that a reconceptualization of the fundamental purposes of the term global as a framing concept in legal studies is proposed. Put negatively, the term "global" does not function here as a descriptive term designating a particular field of social scientific inquiry, nor is it a way

\footnotetext{
${ }^{1}$ The work of William Twining is particularly important in this regard. See WILLIAM TWINING, GLOBALIZATION AND LEGAL THEORY (Butterworths \& Co. 2000) (attempting to define notions of globalism and global constitutionalism); See also

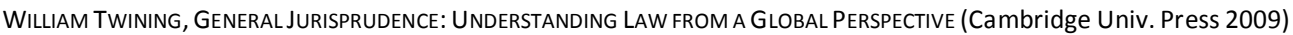
(furthering development of the definitions of globalism and global constitutionalism).
} 
of classifying a discrete range of doctrinal materials for the purposes of a systematic exposition such as in the field of contract or tort law for example.

What sort of re-conception of the global is being proposed here? Following, but also modifying, in critical aspects, Neil Walker's suggestion of treating the term "global" as an indispensable epistemic idea in legal studies, the concept is used here less in order to designate an empirical objectivity chartered observationally than as an attempt to think about the practices and structures within which we develop our own understanding and engagement with the human relations and realities of politics and law. ${ }^{2}$ This is crucially not only a matter of developing the idea simply for cognitive purposes, as the term "epistemic" might seem to imply, but it also informs practical action as well. When we talk about the concept of the global as it relates to practical and cognitive modes of generating collective understanding and identity, it is important to note that the global here designates a fundamental dimension of our post-Westphalian lifeworld: A fundamental category that confers a particular shape or character on our experience of ourselves, our environment, and our relations with others. The sense in which the notion of the global can be seen as disclosing fundamental cognitive and practical possibilities within a given lifeworld is designated here by defining the global as belonging to the fundamental symbolic dimension of the political and social field.

This fundamental and formative dimension of constitutional experience can also be understood in terms of a distinction that has developed in the field of political theory between politics and the political. ${ }^{3}$ This distinction, now better known in general, but not

\footnotetext{
2 See Neil Walker, Intimations of Global LaW 10 (Cambridge Univ. Press 2014) (stating that the case in favor of employing the concept of global law, despite uncertainties surrounding the idea of globalization, reduces to, "one argument comprising three layers-rhetorical, structural and epistemic."). Amongst these three reasons, the third, the epistemic reason, appears to be the most telling. Walker describes this as follows: "[The idea of global law] both reflects and encourages an important shift at the margins in the very way that we think about legal authority and strive to refashion law on the basis of that knowledge." Id. In other words, the most noteworthy aspect of the shift in favor of the use of the category of "the global" is the way in which it marks a change in our fundamental understanding of legal authority. It is precisely this "epistemic" sense of the global that is developed in this Article. In a move that we will discuss later, Walker locates the character of this transformation in the nature of the authority claim made by any given legal system: That it relates in some sense, not so much to a discrete national or local jurisdiction, but to a jurisdiction that is universal in nature. As he puts it, "[W] hat qualifies law as global law, and what all forms of global law have in common, is a practical endorsement of or commitment to the universal or otherwise global-in-general warrant of some laws or some dimensions of law." Id. at 18.

3 See O. Marchart, Post-Foundational Political Thought: Political Difference in Nancy, Lefort, Badiou and LaClau (Edinburgh Univ. Press 2007) (explaining the distinction between the political and politics itself); see also W. BRECKMAN, AdVENTURES Of THE SYMBolic: POST-MARXISM AND RAdICAL DeMOCRACY (Columbia Univ. Press 2013) (describing
} 
without its difficulties in terms of the variety of ways in which the concept has been deployed, maps a very significant distinction between the ordinary activities of politicselections, formation of governments, policies, and political parties-and a prior register that is termed "the political." In summary, "the political" denotes a constitutive set of assumptions that determine several things. First, the assumptions determine formative structures within which agents are constituted and within their actions can take place: For example, institutions, official roles, and so on. Secondly, they develop the layers of significance that provide a meaningful repertoire of actions, including narrative structures, conceptions of the teleology, and modality of social transformation. Finally, and most importantly, they generate the social imaginary itself, the symbolic form as the locus where all possibilities of the constitution are reflected on and developed. ${ }^{4}$

The importance of the distinction between the political and politics, and the accompanying notion of "symbolic form," ultimately lies in the fact that it provides an alternative to the familiar distinction in social science between what Anthony Giddens has described as structure and agency. ${ }^{5}$ It must be noted that what is involved here is a certain way of conceiving of the social field that is broader than Giddens' work and might include work premised upon alternative concepts like that between regime and subjectivity, as described by Foucault, or habitus and agency, as described by Bourdieu. If it does take up the

\footnotetext{
the constitutional experience as a theoretical concept, now understood as the distinction between politics and the political).

${ }^{4}$ This threefold distinction between what might be termed setting, significance, and form is indebted to Claude Lefort's seminal work, which distinguishes between a mise-en-scènce, mise-en-sens, and finally, a mise-en-forme. For Lefort, the term mise-en-scène designates his essential interpretation of the place of the political as the transcendent constitutive moment in social relations as society represents this to itself. Central to Lefort's own conception of the political in this sense is the notion of the transcendent that is understood in terms of MerleauPonty's phenomenology of corporeality in which what is visible is always tied to an invisible transcendent ground. The phrase that encapsulates this is that there is "an excess of being over appearance." On this reading, the political belongs to a fluid and open-ended domain of essentially embodied existential experience which, as such, precedes quotidian political action and theoretical conceptual determination. The political, according to this view, brings a closure to this field of open-ended possibility, and establishes a framework for meaningful action (mise-en-sens), by establishing a central and unifying symbolic point of reference for social interaction. The term mise-en-forme designates this entire set of operations as they are performed within any given society. As we will see, critical to the character of modern democratic society is an unprecedented mise-en-forme that, in its mise-en-scène, represents the key formative dimension of power as essentially open-ended in terms of the persons and ideas legitimately occupying it: This is what he terms the image of the "empty place" of power. We will return to further consider Lefort's work in examining Samuel Moyn's work regarding the "Utopian" consciousness of the human rights movement. See Bernard FlynN, The Philosophy of Claude Lefort: INTERPRETING the Poltical (Northwestern Univ. Press 2005) (outlining Lefort's work in this field); See CLAUDE LEFORT, The Permanence of the Theological-Political, in Democracy AND Political Theory (David Macey trans., Polity Press 1988) (delineating the key elements of Lefort's approach to political philosophy and to the analysis of modern constitutionalism).
}

${ }^{5}$ See Anthony Giddens, The Constitution of Society: Outline of the Theory of Structuration (Polity Press 1984) (describing the distinction between the political and politics). 
underlying problematic pursued through these concepts, the alternative distinction between politics and the political does so within its own framework of ideas.

Crucially, unlike the structure/agency distinction, the political/politics distinction moves away from any stress on a co-dependent and dialectical relation between what is genuinely constitutional and the forms of social agency within the field it establishes as the key transformative element of modernity. This point will be developed in various ways throughout this Article. The approach might be outlined as follows. In all the different and varied contexts in which it is deployed, the notion of the political, in its essential meaning, designates the transcendence of the constitutive moment with respect to the social formation. On this understanding, there can be no synergy between constitutive meaning and the constituted structures of action as such; rather, the generation and development of possibilities for social action are, on the most fundamental level, given entirely through and from the level of constitutive meaning.

In advance of providing a preliminary account of the overall structure of this Article, a brief summary of the preceding points setting out its overall framework can be outlined as follows. The field of human rights appears to represent a key element in the development of a form of global constitutionalism, which has grown out of the previous form of the nation state. This broader form of constitutionalism needs to be understood as a symbolic form in which a collective form of agency and identity establishes itself and which sets the framework for the wider field of social action. The problem is to establish the sense in which human rights discourse occupies a significant and revealing element within this symbolic framework. Accordingly, in the first section of the Article, the hermeneutical and juridical basis for the doctrinal interpretation and application of human rights will be explained in relation to the concept of the global constitution-sketched in the introduction-as a new symbolic horizon shaping legal action. The primary purpose of this part of the Article will be to set out the idea of constitutional theory as a way of reflecting on the critical political decisions embodied in this symbolic setting. The second section will resituate human rights in the global setting, where the "global" is interpreted in the specific sense that has just been outlined. It will also examine some of the work that seeks to establish the centrality and importance of human rights within this field. The third section will engage with the substance of Samuel Moyn's recent important contextual and historical analysis of the significance of the human rights movement. Moyn's work helps to provide an understanding of the context in which the human rights movement, viewed in relation to the formative dimensions of the global constitution, can be clarified. On the basis of his work a critique of the human rights movement might be developed by arguing that the human rights agenda has been guilty of projecting and reinforcing a utopian conception of constitutionalism that has not enabled the problems of a global constitutionalism to be set out and tackled in an appropriate way. Moyn's work stresses how the previous paradigm of the nation-state 
constitution provided the political closure in relation to competing conceptions of personal interests, as well as views of the right and good that was necessary to the formation of a coherent transformative political agency. The human rights declarations formed a key part of this. However, the declarations were subordinate in significance and function to the constitutive form of the nation state. In isolation from this underlying form, as is presently the case in the global context, the same human rights agenda necessarily takes on an abstract, normative, and utopian character. Section four explores possible responses to the human rights that might be drawn out of a reflection on Moyn's work. In contrast to the point of view advanced in section three, but in constructive engagement with some of its central insights, it explores the sense in which human rights can in fact be seen as a central and plausible formative element in global constitutionalism rather than as being a perhaps more peripheral utopian discourse. This view is defended and explained with regard to the work of Michel Gauchet and, in particular, his concept of the distinctive symbolic form of the secularity of modernity. The key implications and tensions present within the human rights discourse, within the global context, can then be set out within this perspective.

\section{B. The Constitutional and the Doctrinal: Questions of Method}

Before clarifying the register and terms appropriate to posing fundamental questions concerning constitutionalism at large and global constitutionalism in particular, a number of methodological points should be set out. First, we need to establish where constitutionalism ought to be located in relation to the social field in general. Second, and for the purposes of further consolidating this interpretation, it is also useful to establish the connection between constitutionalism and the distinction that has been drawn between politics and the political. Finally, some indication of how legal studies can be understood in this context is provided.

To begin with the first point, the relationship between constitutionalism and the social field in general. This is evidently a large topic to discuss in an entirely exhaustive manner. Nevertheless, some leading principles can be set out. A useful starting point in this respect is the work of the sociologist Anthony Giddens. Giddens' "structuration theory" is a significant, influential, and important attempt to mediate between two distinctive models of sociological inquiry: An "objective model," which stresses the priority of social structure to individual agency, and a "subjective model," which stresses the priority of individual agency and subjective meaning in the constitution of the social field. ${ }^{6}$ Giddens' structuration

\footnotetext{
${ }^{6}$ See id. (distinguishing between "objectivist" and "subjectivist" theories although useful in general does slightly gloss over between different approaches within these models). Within the "objectivist" approach, there is a distinction between functionalist or naturalist accounts of the "objective" determinants of the social field and structuralist accounts that focus on the symbolic character of these objective structures. From within the "subjective" approach, Giddens discusses the Verstehen approach pioneered by Dilthey. Other "subjective" approaches might include, for example, rational choice theory, which would be driven by very different
} 
theory instead describes a field of social practice that consists both of structural elements that crystallize over time as well as intentional action that intervenes to operate upon and through these structures with transformative and recursive effects on those same structures.

The primary form of intentional action within such on-going social practice is described by Giddens as being a form of "reflexivity." This involves an intentional and discursive engagement by individual actors with social structures enabling them to formulate objectives and formulate strategies of action. It is tempting to think of the law, and even of constitutional law, as an exemplary set of structures and discourses concerned with reflexive action. Giddens specifies that a distinction needs to be drawn between intentional action, taking the form of "reflexive monitoring" and what he describes as the "motivation" of action. ${ }^{7}$ It is arguably with regard to an enlarged and refocused account of the motivational dimension of action that we need to locate a phenomenon like constitutionalism. Whilst "reflexive monitoring" is a "discursive" process, motivation is a matter of "practical consciousness": A dimension of human action that Giddens describes as relatively opaque to discursive elaboration and better explored in phenomenology and ethnomethodology. Within Giddens' theory of structuration, motivational action appears to play a distinctive role primarily in relation to agents' capacity to project certain possibilities for their meaning based on which further reflexivity may occur. It is in relation to these sorts of issues - of setting forth possibilities and potential courses of action-that constitutionalism, as it is discussed here, needs to be located. This level of constitutional action, associated with what Giddens terms "motivation," might additionally be usefully described as being concerned with the symbolic form of action. Legal scholarship concerned with this dimension of constitutional activity might be termed constitutional theory.

Recognizing that constitutionalism was created prior to the quotidian recursive and reflexive forms is crucial to extending a broader understanding of constitutionalism and establishing the basis for types of social transformation within modernity. Whilst Giddens' notion of "motivational action" provides us with a useful starting point for understanding constitutionalism as a field of activity, forming additional developments and generating more complete general ideas requires more emphasis and in particular emphasis on the formation of possibility and potentiality; further additional developments are needed to generate a more complete general idea. The first step is to recognize that although Giddens'

presuppositions. What follows is a summary of the key elements of his approach outlined in chapter one of THE CONSTITUTION OF SOCIETY.

${ }^{7} / d$. at $6 \mathrm{ff}$. 
notion of reflexivity encompasses a certain amount of dynamic historicity, the theory of structuration is ultimately embedded within the temporal horizon of modernity. ${ }^{8}$ By emphasizing the distinctiveness of constitutional thought and practice, the idea is not to deny the reflexive interaction between structure and agency as an important form of social reproduction in modernity; instead, the idea is to begin to understand how such reflexivity and recursiveness operate as elements within a wider constitutional framework-that of modern democratic society at large. This then prepares the way for a more radical examination of certain constitutional phenomena in relation to the presuppositions of the wider structures of democratic society itself. This might be described as the domain of constitutional theory concerning constitutionalism as a symbolic form of social relations. This Article only explores this agenda insofar as it clarifies the importance of global constitutionalism and of human rights as critical aspects of the way in which democratic society currently organizes itself.

In addition to exploring the field of global constitutionalism and its effects on modern social processes at large, a second important concept elucidates the significance and weight of constitutional phenomena as it relates to the distinction between politics and the political, and how this distinction relates to the problem of political theology. According to Carl Schmitt's well-known statement in his book Political Theology:

[A]Il significant concepts of the modern theory of the state are secularized theological concepts not only because of their historical development-in which they were transferred from theology to the theory of the state, whereby, for example, the omnipotent God became the omnipotent law-giver-but also because of their systematic structure. ${ }^{9}$

The critical insight Schmitt grasped here has subsequently been elaborated in different ways by writers like Laclau and Mouffe, Claude Lefort and Marcel Gauchet; the insight is not merely that the state borrows concepts from theology. Instead, the status of a fundamental constitutional concept like that of the state derives from the structural role that such concepts play in political life. These roles create what Schmitt calls a "systematic structure" that provides a prior set of presuppositions within which quotidian political structures can evolve in the broadly reflexive way Giddens discusses. In that sense, this prior "systematic

\footnotetext{
${ }^{8}$ See id. at xvii (understanding "sociology," by contrast, to be not a generic discipline to do with the study of human societies as a whole, but that branch of social science that focuses particularly upon the "advanced" or "modern societies.").

${ }^{9}$ CARl Schmitt, Political Theology: Four Chapters on the Concept OF Sovereignty 36 (George Schwab trans., Mit Press 1985).
} 
structure" occupies the same place in relation to the social field as that occupied in traditional societies by various religious traditions and representations. Claude Lefort and his notion of mise-en-forme of a society provide another example of how the concept of the political should be understood. The following quotation provides a useful summary and description of the relevant distinctions:

The space called society cannot in itself be conceived as a system of relations .... On the contrary it is its overall schema, the particular mode of its institution that makes it possible to conceptualize... the articulation of its dimensions, and the relations established within it between classes, groups and individuals, between practices, beliefs and representations. ${ }^{10}$

Before proceeding to a discussion of the global constitutional framework, a further clarification might be made of the terms in which constitutionalism operates, this time with respect to the legal system. Once more, it is useful to refer to certain well-known approaches to legal theory in explaining this, although, as with Giddens' work, this should be seen as setting out certain preliminary directions rather than being entirely definitive. The starting point in this instance is the work of Ronald Dworkin, and in particular the ideas advanced in his final trio of major works: Law's Empire, Justice in Robes, and Justice for Hedgehogs. ${ }^{11}$

In his widely acknowledged account of the legal process, Dworkin presents a picture of legal practice on two levels, each setting including different conceptual tasks. First, on the level of the aspirational concept of law, legal interpretation establishes the general ethical significance of the legal enterprise as a constraint placed by past political decisions in the form of precedent and legislation, which in turn confers rights on individuals regarding the future use of coercion by political authorities. According to Dworkin's preferred conception of the aspirational concept of law, past political decisions should constrain the use of coercion by political authorities, but only where the interpretation of the effective legal content of these decisions is itself constrained by underlying principles of political morality explaining and justifying these decisions. This preferred conception of the aspirational concept of law is termed "law-as-integrity." Second, on the doctrinal level, lawyers guided

\footnotetext{
${ }^{10}$ LEFORT, supra note 4, at 217-18.

${ }^{11}$ Ronald DWORKIN, LAW'S EMPIRE (Hart Publishing 1998); RonALD DWORKIN, JUSTICE IN Robes (Harvard Univ. Press 2008); RONALD DWORKIN, JUSTICE FOR HEDGEHOGS (Harvard Univ. Press 2013).
} 
by an aspirational concept of law work out what further specific legal claims to certain rights and duties are capable of being justified by this broader interpretive framework in the context of a particular legal system. In accordance with the idea of law as integrity, the question of which claims are justifiable in this way is best established for Dworkin through a process of constructive interpretation in which, at a preliminary and pre-interpretive stage, the settled meaning of past political decisions is discerned. This is followed by a process in which a set of principles of political morality are assigned to these materials in a way that best explains and justifies them. The analysis concludes with the interpretation of the content and implications of the materials in terms of specific claims, rights, and duties.

In a less discussed and less widely-known dimension of Dworkin's work, it is also clear that he seeks to ground his claims concerning the importance and significance of his model of legal interpretation in meta-ethical theory. This dimension of his work is a constant theme present in Law's Empire and its importance grows in Justice for Hedgehogs, where it is treated at length. It is perhaps tempting for doctrinally focused legal scholars to treat his concern with meta-ethics as somewhat marginal to the core lessons Dworkin's work can teach us about legal practice. The careful attention Dworkin takes in examining the issue suggests that an important point is at stake. This dimension of Dworkin's work is arguably important here insofar as it gestures toward an acknowledgment of the constitutional-or "political"-dimension of legal practice being discussed in this Section. According to this view, Dworkin's meta-ethical framework is best interpreted as part of a hermeneutic debate directed at shaping the way in which problems of public value are first formulated, precisely in what Giddens has termed a "motivational" sense; that is, Dworkin's meta-ethical work sets the spatial and temporal coordinates of legal practice as a prior condition of possibility, the symbolic form of legal practice. Accordingly, Dworkin emphasizes the "objectivity" of the moral principles underpinning his conception of law-as-integrity, thus sustaining its legitimacy as a way of ordering the public sphere. Further, Dworkin emphasizes the sense in which such "objectivity" is sustained by its capacity to maintain a normative coherence and unity across a range of contemporary legal rights and claims, as well as a sense of narrative coherence over time. In both these senses, Dworkin's meta-ethics serves to shed light on the presuppositions through which law-as-integrity is advanced-on the constitutional or "political" level-as a way of defining the critical parameters through which legal practice itself becomes possible as a meaningful and legitimacy-generating symbolic form of legal activity. The task of constitutional theory is precisely to explore concepts like law-as-integrity and how they operate in relation to fundamental assumptions as to the narrative unity and objectivity of public value as Dworkin presents it in his meta-ethical work.

\section{Problematizing the Global Human Rights Model in Context}

Having clarified certain key aspects of the methodological approach adopted in this Section the global model of human rights, will be examined more closely from the perspective of constitutional theory. The predominant focus will be on tracking the evolution of the globalization of human rights and on exploring the problems of how their doctrinal 
development can be organized on a principled basis. The critical point that will be developed in this Section is that the importance of the "global" discourse of human rights is occluded if the formative elements of the practice of human rights are not properly clarified. Although normative attempts to secure a principled "global" conception of human rights are useful, they arguably do not adequately clarify the more dynamic formative role played by human rights discourse within the global constitution.

Understanding the formative function of human rights is difficult in part because of our inheritance, through the liberal constitutional tradition, of an understanding of human rights as foundational for social relations as opposed to a broader notion of the complex process of social formation. From this inherited perspective, a narrative of human rights can be laid out, presenting human rights as a self-evident component of any legitimate constitutional framework. We can accordingly draw a line originating from the natural rights discourse developed by John Locke, through the American and French revolutionary settlements, down to the Universal Declaration of Human Rights in 1948. This continues to the progress made in actualizing and enforcing that framework and, according to this account, now forms a critical element in the development of a global interpretation of that same human rights framework. Within this narrative framework, the key point is that human rights are presented as a timeless and universal core of constitutional standards that necessarily emerge and are recognized and reinforced over time within various political regimes that are shaped by the same basic liberal presuppositions as to the priority of individual rights. The argument and perspective of this Article, as it emerges over the course of the next set of sections, will try to make sense of the central importance of the human rights tradition within liberal constitution. At the same time, this Section will also attempt to show that the straightforward foundational role of individually indexed rights within the liberal tradition is inefficiently nuanced. In particular, it fails to account for their role in providing a symbolic form through which the collective agency of democratic society is made possible.

The traditional liberal view of the foundational importance of human rights has continued into the present era. Accordingly, the field of human rights law can increasingly become central within a broader paradigm and understanding of law associated with global constitutionalism. This means that human rights are no longer simply one discrete, institutional process or legal idea. Rather, human rights have attained a foundational constitutional status. They not only appear in the documents that form part of the written constitutions of states or the charters of international organizations, but they also constitute, on a deeper level, the basic grammar in which law and politics are conducted. The difficult question that needs to be posed with increasing urgency in the context of current developments is whether it is plausible and practical to transfer the traditional foundational conception of human rights into these new circumstances. 
A good starting point for considering these developments is the work of Kai Möller, who has usefully outlined the basic character of what he terms the sphere of the "global constitutional rights." ${ }^{12}$ Möller's account of global constitutional rights follows an account that falls under the liberal foundational tradition and stresses the capacity for human rights or liberal constitutional rights to act, in a free-floating manner, as essential generative elements of legitimate governance. For example, he stresses that:

[I]t is emphatically not the case that the moral demands of constitutional rights are inextricably linked to and intertwined with a particular constitution with a particular interpretative history, adopted by a particular political community at a particular point in time. Rather, constitutional rights discourse is governed more by "free-standing" moral argument about what rights and legitimacy require than by considerations relating to the history of a document or people. Constitutional rights discourse has gone global. ${ }^{13}$

Upon closer examination, the eventual conception of global constitutional rights that Möller develops from this starting point does not stress the foundational role of such rights in a straightforward sense. Rather, their distinctive role is that they serve as a model for developments in an interconnected set of judicial processes, concerning constitutional rights and involving national, supranational, and international bodies. Möller sets out a two-stage model of global constitutional rights in which, first, an interest is protected as a right and, second, any interference with such a right by a public authority is subjected to the defense of justifiability. ${ }^{14}$ That test typically takes the form of proportionality and this is where the bulk of the argumentation takes place. ${ }^{15}$ The model provides a normative reconstruction from a set of empirical features common to different types of process.

\footnotetext{
12 Kai Möller, The Global Model of Human Rights (Oxford Univ. Press 2012); Kai Möller, From Constitutional to Human Rights: On the Moral Structure of International Human Rights, 3 GLOBAL CONSTITUTIONALISM 373 (Cambridge Univ. Press 2014) (concerning the category of "constitutional right," and overlapping sufficiently with what is defined as a narrower category of human rights. Nevertheless, in terms of the wider focus on the role of rights within constitutionalism at large (the focus of the present Article), this set of distinctions is less important).

${ }^{13}$ MöLLER, supra note 12 , at 376.

${ }^{14}$ Id. at $376-77$.

${ }^{15}$ See id. at 377 ("In judicial practice, the first stage has become less and less important, largely as a consequence of rights inflation, that is, the phenomenon that more and more interests are protected as rights.").
} 
Two critical points need to be made about this way of construing the role of constitutional rights within an avowedly global model regarding the status of the model and its substance. First, its status as a model of how global constitutional rights are-and how they ought to be-adjudicated appears less as an insistence of foundational rights in terms of global constitutionalism and more as a particular procedure or model of judicial rights adjudication that provides a suitable element within the broader formative process of global constitutionalism. Second, the question then shifts to how this broader formative process could possibly be conceived. In terms of substance, the emphasis on the proportionality element of the test means that, although the model disavows the notion of the dependence of global constitutional rights on context, it nevertheless appears to bring such constitutional and social context back in, insofar as judges will have to make assessments about where the balance lies in any instance where a right is weighted against some local policy justification. These issues point to the further necessity of reflecting on the formative role of rights within the wider symbolic framework of governance and policy instruments associated with globalization especially where the global context of such assessments is also brought into consideration.

\section{Moyn and Human Rights Utopianism}

Samuel Moyn's work examining the recent historical development of the modern human rights movement in the context of the social and economic changes of globalization provides an interesting and important map of the range of issues involved in developing the problematic posed in the previous section: Namely, the contextual factors that have shaped the emergence of a certain global model of human rights as a key formative part of the developing discourse of global constitutionalism. ${ }^{16,17}$

The central thesis in Moyn's major work, The Last Utopia, is that the increased importance of human rights in the global context is driven by a loss of faith in collective institutional and political processes as a means of achieving social self-determination and unity. Moyn links this loss of faith not so much to the collapse of Communism in Eastern Europe in 1989 as to

\footnotetext{
16 SAmuel Moyn, The Last Utopia: Human Rights in History (Harvard Univ. Press 2010). For a critical discussion of Moyn's work, see Philip Alston, Does the Past Matter? On the Origins of Human Rights, 126 HARV. L. ReV. 2043 (2013) and Christopher McCrudden, Human Rights Histories, 35 OxFORD J. LEGAL STUD. 179 (2015). Subsequent discussions of Moyn's book, THE LAST UTOPIA, refer to the edition cited here.

17 See LyNn Hunt, INVENTING Human RightS: A History (W.W. Norton \& Co. 2007) (engaging in an examination of the historical context of the emergence of human rights with a view to clarifying and specifying their present role and function, comparable to the work of Samuel Moyn); see also JENNY MARTINEZ, THE SLAVE TRADE AND THE ORIGINS OF INTERNATIONAL HUMAN RIGHTS LAW (Oxford Univ. Press 2012) (examining human rights and clarifying human right's role and function within the context of constitutionalism, also similar to the work of Samuel Moyn).
} 
an earlier set of disappointments in attempts to bring about democratic change in Eastern Europe and Latin America from the late 1960s to the early 1970s. Replacing the mobilizing ideals that depended on a unified sense of collective agency, human rights instead supplied an alternative politics of categorical moral demand capable of being made by individuals and more decentered groups of agents. ${ }^{18}$ The exact point of Moyn's critique needs to be determined carefully. If we examine certain of his other works in addition to The Last Utopia, it becomes apparent that the human rights movement is problematized not so much for the individualistic features of its ideal, but for its utopianism. Further, this utopianism is not only characteristic of human rights but of a range of different ideals associated with the revolutionary self-consciousness political modernity; hence, it is precisely the last utopia.

A work Samuel Moyn wrote on the influential philosopher Emmanuel Levinas provides the context for this far wider skepticism concerning the utopian idea of social transformation. ${ }^{19}$ The work charts a little-known development from nineteenth century liberal Protestantism through to the "neo-orthodox" theology of Karl Barth (1886-1968) and on to the work of the philosopher Emmanuel Levinas (1906-1995) and it follows what we might, for general purposes, classify as a Durkheimian approach to the historical sociology of modernity that emphasizes the role of religion, understood in a broad sense, in social integration. ${ }^{20}$ Moyn's work on the genealogy of elements of the discourse of human rights utopianism traces it from Levinas back to Karl Barth's critical engagement with liberal Protestantism. ${ }^{21}$ Karl Barth's engagement with liberal Protestantism contested a deep assumption that had underpinned a great deal of thinking about the nature of the state and of liberalism during the nineteenth century. This line of thinking-emerging from Rousseau's and Kant's work and reaching its most decisive philosophical articulation in the work of G.W.F. Hegel and, in a more theological idiom, in the work of Freidrich Schliermacher-was concerned with establishing the principled coherence of the nation-state form of liberal constitutionalism as

\footnotetext{
${ }^{18}$ MoYN, supra note 16 , at 8.

The best general explanation for the origins of this social movement and common discourse around rights remains the collapse of other, prior utopias, both state-based and internationalist. These were belief systems that promised a free way of life, but led into bloody morass, or offered emancipation from empire and capital, but suddenly came to seem like dark tragedies rather than bright hopes.
}

${ }^{19}$ Samuel Moyn, Origins of the Other: Emmanuel levinas Between Revelation and Ethics (Cornell Univ. Press 2005).

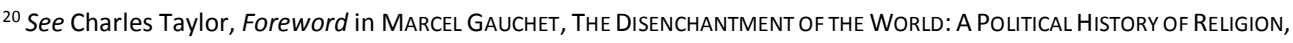
at $x$ (Oscar Burge trans., Princeton Univ. Press 1997) (explaining that, according to this approach, religious ideasincluding concepts like secularism - provide a symbolic form for "the way we experience or belong to the larger social whole.").

${ }^{21}$ See Mark Lilla, Religion, Poltics AND the Modern WeSt (Vintage Books 2008) (making a similar stress on the link between twentieth-century utopianism and the political theology and nineteenth-century liberal Protestantism). 
the product of a distinctive human process of self-development. ${ }^{22} \mathrm{~A}$ certain approach to theology and religion that saw it as a hermeneutic attestation of this process of self-development, albeit in some cases superseded by philosophical discourse, accompanied this approach to the legitimation of constitutionalism. Liberal Protestantism can thus be argued to have contributed to an ideology of social unity that served to mask the increasing social tensions of a more dynamic industrial society experiencing its own process of globalization. Equally, it was also possible to frame a more revolutionary understanding of democracy in which social unity and the overcoming of division was the task for future development. This was the line taken by the left-Hegelians like Bruno Bauer and, most notably, Karl Marx. Such currents could also draw comfort from a certain kind of teleological and eschatological reading of the historical process of change inaugurated by the secular form of modern society. These symbolic elements within revolutionary politics were reinterpreted and developed in later Marxist writers such as Ernst Bloch (1885-1977). ${ }^{23}$

As Moyn in Origins of the Other presents it, Karl Barth's central critique of liberal Protestant view was that theology was not able to offer any strong ethical critique of society and state and was thus condemned to play a narrowly ideological role. These dangers and questions evidently became more pressing to Barth after the First World War and were later to resurface even more urgently during the 1930s. Barth sought in particular to problematize the relationship between theology and the social formation. The social formation, in this sense, could no longer be seen as the outworking of an Absolute embedded in the dialectical turns of history, as it had been for Hegel. It is at this point that we can rejoin Moyn's analysis and the human rights movement and we can reconstruct in its key insight as follows. The basic direction of Moyn's analysis points-across the Levinas book and The Last Utopia-to the wider historical and sociological transposition of Barth's theology of divine alterity with respect to the ethical underpinnings of the social order. Accordingly, it articulates a certain social experience of alienation and disorientation and the attempted recovery of a commanding and infinite ethical imperative but one that was eventually located in the field of quotidian intersubjective relationships. ${ }^{24}$ This was a basic stance that was ultimately eloquently articulated by Emmanuel Levinas, and Moyn's later work suggests a close association between this position and the underlying impetus of the human rights

\footnotetext{
22 See Gary dorrien, Kantian Reason and Hegelian Spirit: The Idealistic logic of Modern Theology (Wiley-Blackwell 2012) (thoroughly accounting nineteenth century ideology).

${ }^{23}$ See COSTAS DOUZINAS, THE END Of HUMAN RIGHTS (Hart Publishing 2000) (seeking an alignment between the human rights movement and the utopian elements of the revolutionary tradition).

${ }^{24}$ See Moyn, supra note 19, at 113-64 (tracking the development of ideas from Protestant liberalism, through Barth and also the religious philosopher Rosenzweig to Levinas in more detail).
} 
movement. The point of this distinctive approach to the ethical problems embodied in modern life, articulated in theological terms by Karl Barth and in philosophical terms by Emmanuel Levinas and eventually underpinning, as Moyn's overall analysis implies, the human rights movement, is that it justified the formulation of stringent ethical demands for existing social relations, without folding such demands and ideals back into the existing social order or projecting such a social order as a task to be definitely realized in a utopian future, as with revolutionary Marxism. ${ }^{25}$

Moyn's work, constructively interpreted as a whole, initially appears to lend itself to forming a skeptical assessment of the importance and utility of human rights within a global context. According to this skeptical view, human rights as a global "model" or movement appears to provide discourse that has become detached from the classic tradition of liberal constitutionalism connected to the form of the nation state. It responds to a set of concerns about social conflict and division, set in motion by the dynamics of a modern secular society of global dimensions. In reaction to the dangers of a complacent consensus or of the pursuit of a political vision of utopia, it articulates a basic form of ethical demand capable of tackling these concerns and reestablishing an overall direction and coherence to the complex formations of secular society. While the transcendent ethical imperative of the human rights movement of the "last" utopia eschews any unified project for the political resolution of social division, it nevertheless implies an overarching idealistic diagnosis of a set of problems and prescriptions for immediate responses that are equally ambitious and indeterminate in nature. Consequently, to avoid the problematic expectations and assumptions raised by seeking a wider, more utopian role for human rights, expectations that might well have distortive impacts on the functioning of other societal institutions, it appears that we are called back to a cautious, modest, and incremental view of their role on a global level. ${ }^{26}$

At this point, it is difficult to determine where human rights and constitutional lawyers seeking to define an ethically grounded but appropriately cautious understanding of human rights might gain a more realistic direction in planning various interventions and proposals of reform. The principal consequence of such caution and skepticism seems to be that a global human rights movement will collapse into a relatively self-contained discourse, turning inwards for self-direction. In this sense, it would come close to instantiating the sort

\footnotetext{
${ }^{25}$ See id. (noting crucially that the claim here does not argue for a causal link between Levinas and the human rights movement as it develops in the 1970 s but rather a more basic solidarity in their basic ethical position).

${ }^{26}$ See Morn, supra note 16 (concluding in his prologue that there is a paradox between the ambition of the human rights movement and its minimalistic approach to problems of collective political action). A similar set of skeptical concerns about the indeterminacy and institutional lacunae of the human rights movement have been articulated more directly by the political philosopher and sociologist Marcel Gauchet in two important articles. See Marcel Gauchet, Les droits de l'homme ne sont pas une politique, LA DÉMOCRATIE CONTRE ELLE-MÊME (Gallimard 2002) (1980), and Marcel Gauchet, Quand les droits de l'homme deviennent une politique, LA DÉMOCRATIE CONTRE ELLE-MÊME (Gallimard 2002) (2000).
} 
of auto-poetic or self-referential "social systems" logic theorized by writers like Luhmann and Teubner. ${ }^{27}$ With the loss of its utopian aspiration in terms of its capacity to address itself to social development in its universal aspects, human rights would simply belong as one component to the process of social differentiation itself.

This skeptical diagnosis with its accompanying somewhat hermetically pragmatic agenda, which we might be tempted to draw from Moyn's work, may yet be somewhat precipitous in so far as a crucial presupposition of Moyn's analytical template needs to be examined more closely. Although playing a background role in The Last Utopia, Moyn has also engaged in a careful analysis of Claude Lefort's understanding of modernity, in particular, against the backdrop of the work of the French anthropologist, Pierre Clastres. ${ }^{28}$ While Moyn is cautious in drawing normative implications from Lefort's work, it might be argued that Moyn's somewhat skeptical analysis in The Last Utopia and certainly any further normative conclusions we might be tempted to draw from it are in fact capable of being underpinned by certain sorts of conceptual moves that derive from Claude Lefort's construction of modern constitutionalism. As we shall see, at first glance, Lefort's work might reinforce the skeptical conclusions that have been drawn and serves to elaborate their basis.

From this Lefortian point of view, the key problem with the utopian interpretation of human rights is that it is derived from an understanding of modern politics that sets, implicitly or explicitly, a standard of social unity as the central criterion for assessing historical development. This is inappropriate to the basic character of modern democratic society that is constituted by a symbolic form that does not anchor social development over time to an immutable "law of origins." ${ }^{29}$ Instead of this, modern society is constituted in accordance with essentially open symbolic structures that enable social space to be open to a plurality of social differences and identities. Such structures also condition the emergence of a distinctive form of historical temporality to in which future horizons of possibility shape and

\footnotetext{
27 See Gunther Teubner, Constitutional Fragments: Societal Constitutionalism and Globalization (Oxford Univ. Press 2012) (providing a useful discussion of globalization from a systems-theoretic perspective); see also CHRISTIAN BORSCH, NIKLAS LUHMANN (Routledge 2011) (providing a useful clarification of the key theoretical underpinnings of the concepts of autopoesis and systems theory).

${ }^{28}$ Samuel Moyn, Claude Lefort, Political Anthropology and Symbolic Division, in 19 CONSTELLATIONS 37 (2012); Samuel Moyn, The Politics of Individual Rights: Marcel Gauchet and Claude Lefort, in FRENCH LIBERALISM FROM MONTESQUIEU TO THE PRESENT DAY (Raf Greenens \& Helena Rosenblatt eds., Cambridge Univ. Press, 2012); see also Samuel Moyn, Of Savagery and Civil Society: Pierre Clastres and the Transformation of French Political Thought, 1 MODERN INTELLECTUAL HISTORY 55 (2004).

${ }^{29}$ See generally Bernard Flynn, The Philosophy of Claude Lefort: Interpreting the Political (NW Univ. Press 2005) (providing an overview of Lefort's work generally): See also LEFORT, supra note 4 (discussing in more detail Lefort's work on the issues discussed here).
} 
determinate the sense of the present and past. In that sense, visions of social unity developed within a modern horizon that attempt to close off its spatial and temporal openness represent a dangerous atavistic temptation that is all the more dangerous for the powerful resources for social transformation made available by modern societies.

At the same time, as well as reinforcing the skeptical conclusions we might be tempted to draw from this body of work, Lefort's work stresses the fact that not only is the open-ended character of modern constitutionalism supported negatively through suspending any kind of ideal of social unity, whether backward or forward looking but also Lefort tends to emphasize the role played by democratic institutions and processes of contestation in maintaining and establishing this sense of openness and of transformative possibility. ${ }^{30}$ This latter emphasis in Lefort's work, on the role of liberal-democratic institutions in establishing the symbolic space of modern politics and society appears to support the strong connection Moyn insists on throughout The Last Utopia, between the classical structures of the nation state and human rights. Such a connection might be supported on classic Hegelian grounds, namely that the abstract moral demands embedded in human rights claims are only supportable and effective within the complex "ethical life" of the nation-state comprising family life, civic association, and the political constitution. Such a vision of social unity, centered on the nation-state, is unavailable from within Lefort's perspective on constitutional modernity. Nevertheless, from this point of view, an argument might still be made that a political association with the comprehensive juridical scope of the nation-state is still necessary to actualize the symbolic functions of modern constitutionalism, albeit with the important complementary role played by human rights in holding open the social space of contestation given the hegemonic capacity of the state. ${ }^{31}$ The final picture that emergesif we accept a Lefortian inspired analysis of contemporary events-is paradoxical, as the very complex process of social differentiation that characterizes a global society premised on a constitutionalism that constructs an open symbolic space and temporality ends up weakening and decentering the very institutional structures-the nation state and its connected framework of human rights - that were responsible for initiating the process.

How do we move beyond the cautious skepticism that emerges from this Lefortian analysis of modern constitutionalism and, derivatively, of human rights in the context of global constitutionalism? Part of the answer lies in a subtle re-thinking of the nature of modernity as a society characterized by an "open" symbolic form. As we will see in the final section, Marcel Gauchet's extended engagement with Claude Lefort's emphasis on the symbolic dimensions of modernity is of considerable assistance in this task.

\footnotetext{
${ }^{30}$ See LEFORT, supra note 4, at 224-27 (discussing this concept in more detail).

31 See Claude Lefort, Politics and Human Rights, in The Political Forms of Modern Society: Bureaucracy, Democracy AND TOTALITARIANISM (John Thomson ed. and trans., MIT Press 1986) (discussing the importance of human rights in the scope of the nation-state to actualize symbolic functions of modern constitutionalism).
} 


\section{E. Human Rights and the Global Constitution as Symbolic Form}

In this final Section, the uncertainties surrounding the role of human rights in the context of global constitution will be explored largely in relation to the work of Marcel Gauchet. Gauchet's work, like Lefort's, emphasizes the importance of the symbolic role of constitutionalism in the shaping of a modern society. By paying close attention to Gauchet's conception of how this register operates in contemporary society, we are able to move beyond the prima facie skepticism concerning the role of human rights that Moyn's work, taken in conjunction with Lefort, might initially invoke.

It is important to begin a review of the key elements of Marcel Gauchet's work with his idea of modern society as essentially secular in character. This idea was developed in a number of places and in particular in the thorough genealogy of modern society developed in his best known work, The Disenchantment of the World. ${ }^{32}$ Gauchet presents us with the idea of secular society as constituted by developing a historical consciousness of itself as organized in accordance with a changing set of structures and forms that it has generated for itself out of what it has inherited from the past, and that relate to an uncertain and mutable future. Linked to this historical understanding of its changing structural forms, and brought about as a result of this fact is an understanding of individual identity as distinct from the social matrix. Such an understanding is produced both by the secular process of structural change, and by the sense in which such change is understood as effected by the institutionally mediated collective empowerment of associative action.

How is such a secular society, characterized by its entrance into a dynamic experience of historical development, constituted as such? The secular society is, according to Gauchet, brought about by a gradual withdrawal from an intellectual and symbolic horizon shaped by what he terms "religion," understood in a public and political sense. Religion functions in this way as a socially instituted symbolic form through which the essential organizing divisions of a society are projected, through religious and other symbolic motifs, precisely as ineluctable and predetermined formations necessary to the very identity, unity and legitimacy of the society in question. The emergence of a secular society is the result of a profound symbolic shift in the relationship between social organization and religious conviction, a development that Gauchet ascribes primarily to the growing influence of the Judeo-Christian understanding of the transcendence of God to any given social formation. This transcendence of the divine in respect of the social order, allows, paradoxically, for a space to emerge for conceiving of political organization in essentially secular terms. While

${ }^{32}$ GAUCHET, supra note 20. 
the details and legitimacy of Gauchet's overall thesis need not concern us for present purposes, the principal insight that Gauchet's genealogy provides us with is that the emergence of a secular democratic political form occurs as a mutation in the symbolic form of society. In sum, the shift in question thus involved a gradual withdrawal of a priori religious representations of legitimate political and social authority. Not only do the divisions through which society organizes itself emerge in a more transparent manner, but due to the loss of their ineluctable and incontestable status, the structures through which these divisions are organized are themselves opened up to a dynamic process of historical development and transformation.

For Gauchet, a politics of symbolic representation plays a distinctive role in secular modernity. Given secular modernity's open-ended manner of organizing itself, its openness to an historical process of transformation, the function of politics is reconceived by Gauchet less as a central coordinating power, although many coordinating functions are in turn enabled through this process, than as a power whose function is precisely and primarily to represent society's open-ended historical identity to itself. Gauchet describes this function, in line with his overall understanding of the development of secular society, as "symbolic." At this point, it is useful to set out what exactly the function of representation entails in this sense..$^{33}$ First, and most straightforwardly, it is not cognitive: It does not present society's objectivity and identity to itself as a matter of scientific understanding. The de facto forms of social co-ordination are exactly what will be developed from this starting point. Second, symbolic representation, as Gauchet attempts to articulate it, is best seen as distinct from social construction. This is an important point because it distinguishes Gauchet's notion of secular democratic society from what might be described as "Rousseauian" versions that emphasize self-determination. Without further consideration, the Rousseauian model is the natural way in which we would seek to represent political power, certainly when considering it entirely from within a legal and especially a constitutional standpoint. Accordingly, then, the "symbolic" representative function involved is not a matter of the political instance setting out an idea or direction for social organization and then implementing and enforcing this through various institutional means. Rather, representation functions in a context shaped by the open-ended historical horizon of secular social and political relations and a closed project of self-determination does not lie within its grasp. Essential to the symbolic function of political representation is the dimension of what, as we have discussed, Giddens might describe as "motivation" or "practical consciousness." In other words, it establishes transformational projects and structures but it does so by presupposing a horizon of secular change, more as a matter of practical know-how, within which such projects are carried out.

33 Marcel Gauchet, L'Expérience Totalitaire et la Pensée de la Politique, in LA Condition Poltique at 455 et seq. (Gallimard 2005). 
This function of symbolic representation is perhaps best understood as present throughout a modern society, and not located in any particular instance: Its critical role is always to make available a grasp of fundamental possibilities of change and development-the social space as such-as the symbolic form underpinning any intentional project. The key function of political representation, as a fundamental type of social activity, is to maintain, set out, and recall secular social action back to its conditions of possibility. Gauchet's wider historical account of the origin of the secular matrix of society, appears to suggest that he places less emphasis than Lefort does on the notion of a mise-en-scène: Of a public "staging" of the place of power as empty. Certainly, on the basis of Gauchet's wider discussion of the broader historical currents underpinning secularism, it might be argued that the symbolic continuity of modernity is not so much a matter of political power or any other type of power itself generating and maintaining the sense of secular social space and historical consciousness, but rather of exercises in recalling it and reviving an understanding of it in a plurality of contexts. Furthermore, this would enable the function of political power in its representative sense to be complemented by various social movements that enter into contests over the current organization of the social field and also serve precisely the same ends. ${ }^{34}$ This type of contestatory and developmental action further exemplifies the nature of the symbolic functions of politics as linked primarily to the presupposition of action, rather than to its intentional or discursive content. As an inherently dynamic process, it is also possible to see how the current network of institutions and processes that make up a "global constitution" might be inherently and coherently linked to the historical development of secular modernity, replacing previous forms and structures, such as that of the primacy of the nation state.

What finally of human rights within this picture of the "secular" constitution of modern society? As we have seen, Gauchet shares some of the skeptical views that we might be capable of drawing from Moyn's work. Gauchet is particularly alert to the danger that the individualism that is a product of the withdrawal of religious representations from their symbolic role in social development can develop an illusory emphasis on the independence of its own self-conceptions, at the expense of an understanding of the complex social matrix that forms its effective presupposition. Human rights according to this view represent a double illusion insofar as they harness this type of individual focus to a broader agenda of symbolic change-the human rights movement-constructed precisely out of these sorts of individually-indexed demands, but which, like other modern "utopias," is directed at establishing some kind of overarching strategical and normative direction to the process of secular transformation and differentiation. In the case of its individual focus, the human rights movement risks occluding the wider social matrix and associated social institutions in

${ }^{34} / d$. at $459-62$. 
managing the social transformation in modernity. In the case of its utopianism and its desire to impose a normative grid on the process of transformation it perhaps ignores the radical futurity and openness to which secularism and, by extension, individually-indexed rights movements are committed.

However, an alternative construction of human rights is possible and indeed becomes more plausible once the global and decentered structures of the present constellation of secular authority are understood. Once we see, after Gauchet, the crucial and fundamental importance of the deep historical structures underpinning the secular dynamism of modern societies, then we can see how human rights are potentially detachable from a particular type of institutional structure, such as the nation state, which represents not so much a fundamental political category, but rather one means of organizing action within a broader framework of social interaction. From this perspective, global constitutionalism, far from representing a world-historical departure from the Westphalian state, instead presents a fresh constellation of institutions and forms of co-ordination within a symbolic order that in essential respects has remained the same. The human rights movement, however imperfectly, addresses, reveals, and problematizes the social and existential conditions of the possibility of a constitutional framework that secures the secular symbolic form of modern politics. At the core of this secular dynamic, as it now sustains itself, is that it involves an existential refusal of personal identity being determined in accordance with a heteronomous law by political authorities that usurp the space of essential historical conditions and possibilities. With its basis in the notions of autonomy and dignity, this kind of recollection of the basis of these personal claims in the symbolic forms constitutive of secular social relations is precisely what the "global constitutional rights" model emphasizes. At the same time, the indexation of this model to a proportionality review that places this demand in conjunction with wider social necessity and policy imperatives arguably serves to counter-balance its individualistic dimensions with reference to questions of social solidarity. It is thus arguably this more basic and also more pragmatic and limited symbolic function rather than the utopian and overarching function of human rights that will become more plausible and prevalent within the present global constitution. 